\title{
GOOD RUTS, BAD RUTS
}

\section{by Peter G. Kevan*}

In the March 1972 issue of Blue Jay, Dr. W. O. Kupsch writes of the confusion he finds in the description by Dalton Muir in the December 1971 issue of Blue Jay of ruts on the tundra. Dr. Kupsch points out that the ruts made by settlers' wagons crossing the prairie are historic sites, while those across the tundra are described by $\mathrm{Mr}$. Muir as "scars on a fragile environment." Dr. Kupsch finds further confusion in assessing caribou trails, which he describes as "a natural destruction of the environment" and "'Acts of God" ". I would like to attempt to clarify the apparent dilemma and demonstrate that the three types of ruts considered by Dr. Kupsch are not really comparable in the terms of his presentation.

First, a comparison of the man-made ruts is worthwhile. It should be noted that the ruts across Saskatchewan could be erased from the landscape by deep ploughing, as have been the ruts of sections of many of the historical trails in Canada and the U.S.A.

Ploughing up ruts on the tundra, on the other hand, would only aggravate the situation, probably causing considerable subsidence as the result of the evaporation of water from the pormally frozen ground-ice and permafrost (see MacKay 1970). Also, revegetation is generally far slower in the arctic, and in some extreme examples has hardly commenced after more than 20 years (Hok, 1971). The slowness of revegetation increases the notential danger from erosion, slumping, etc., as the ground remains unpound by roots and subject to the ction of weather and frost for much onger periods of time. Hence, rut creafion on the tundra presents more of a Eerious potential problem than on the prairies. It is that fact, among others,

Note: Dr. Kevan has worked widely as an Arrtic Biologist. He is now at the Plant Refearch Institute, Department of Agriculture, ittawa. that requires the tundra to be regarded as more delicate or fragile than other biomes. Aspects of conservation and the effects of industrial man's activity on tundra are discussed more fully in Fuller and Kevan (1970), Kevan (1971a), Legget and MacFarlane (1972), and others.

It is not that many of the effects of tracks and ruts are peculiar to the tundra. After all, gullying, slumping, sheet erosion, etc., are not uncommon in the south, where they are often the result of incorrect land use practices and carelessness. As it has been proved that tundra is more susceptible to man-made damage or disturbance, however, extra care and knowledge are necessary for operating on it.

While I agree that Parry's ruts across Melville Island made in 1820 are of historical interest, and compare, therefore, with Saskatchewan's Boundary Commission Trail (the example used by Kupsch), I cannot agree that ruts of the commonness with which they criss - cross the Tuktoyaktuk Peninsula have now, or ever will have, much historical value. Part of historical value lies in rarity, the other part in significance. The significance of the tundra scars is known in relation to oil exploration, over-consumptive economy, and their being a stark, displeasing and lasting reminder of some colossal blunders and gross carelessness which could have been avoided. Given that they have that historical significance, they are hardly rare, or likely ever to be so since they appear to last indefinitely. Dr. Kupsch quotes Alcock's (1947) mention of "as many as twenty parallel ruts" from the historic Red River cart trails across the prairie; Mr. Muir's photograph of tundra (1971) shows at least 22 , the result of oil exploration vehicles. Also, the trails described by Alcock resulted from "carts, in brigades, often one hundred strong, 
[which] usually travelled in single file along trails that are followed year after year" (p. 35), whereas those photographed by Mr. Muir are each the result of a single passage. Dr. Kupsch neglects to mention these differences. Furthermore, the Red River carts probably exerted greater pressure on the ground than most tracked vehicles used on the tundra.

I suggest that the tundra and the prairie are very different in their relative capacity to absorb man-made disturbance. On the tundra the ruts cannot be erased, represent potential hazards or problems in some places, and, because of their commonness and apparent permanence, will have little or no historical value. On the other hand, the ruts in Saskatchewan can be eradicated, do not represent any form of a problem other than a slight bump to overland driving, and are sufficiently rare and of great enough significance to have considerable historical value.

Second, an examination of animalmade ruts and trails is in order. In terms of the aesthetics of landscapes and natural environments, it is not realistic to compare animal trails with artificially made ruts, even though it might be considered objective to do so. I cannot agree that the trails trampled by migrating caribou constitute "destruction of the environment" as Dr. Kupsch claims. Except in special places where some disruption may occur, such as on mountain passes, isthmuses, and other land forms which force the animals together, migrating caribou follow a myriad of interlacing trails. Their hooves individually pock the ground, flattening vegetation. The result is not a continuous line of evenly depressed vegetation, as results from vehicle movements; nor is the vegetation continuously cut into small rectangles which may be broken loose, as can result from a tracked vehicle's passing. Thus the trails of caribou are less likely to alter drainage patterns, particularly since caribou fan out in wet meadows, which may be susceptible to drainage; and tend to follow easier rather than direct routes, particularly following contours of hills, so avoiding steep pitches, embankments, etc., which may be susceptible to erosion. Vehicles, on the other hand, tend to travel more or less direct routes up and down fall-lines to save time and to avoid tipping over. Also, caribou do not cut and kill vegetation in continuous strips. Kevan (1971b) has described the sorts of effects from tracked vehicles and points out that sedge-meadows can be, and are being, slowly drained as a result.

I hope that this essay has helped explain the confusion brought out by Dr. Kupsch, and has demonstrated that random, unrestricted, vehicle traffic should not be permitted on the tundra.

The arguments I have presented show that the value systems of historians and conservationists are not at loggerheads, but rather that they cannot be compared in relation to this "rutty" problem.

\section{LITERATURE CITED}

Alcock, F. J. 1947. A century in the history of the Geological Survey of Canada. Nat. Mus. Canada Special Contrib. No. 47-1, vii $+94 \mathrm{pp}$.

Fuller, W. A., and P. G. Kevan (Editors). 1970. Proceedings of the Conference on Productivity and Conservation in Northern Circumpolar Lands. Edmonton, Alberta, 15 to 17 October, 1969. International Union for the Conservation of Nature and Natural Resources, Morges, Switzerland. Publication in The New Series No. 16, 344 pp.

Hok, J. 1971. A reconnaissance of tractor trails and related phenomena on the North Slope of Alaska. U.S. Dept. of Interior, Bureau of Land Management. $66 \mathrm{pp}$.

Kevan, P. G. 1971a. Oil under the tundra in the Mackenzie Delta Region. Can. FieldNat. 85-99-100 and 122 .

Kevan, P. G. 1971b. Vehicle tracks on high arctic tundra: an 11 year case history around Hazen Camp, Ellesmere Island, N.W.T. Defence Research Board, Ottawa; Operation Hazen No. 41. 17 pp.

Kupsch, W. O. 1972. Reflections on ruts. Blue Jay $30: 69-70$.

Legget, R. F., and I. C. MacFarlane, (Editors) 1972. Proceedings: Canadian Northern Pipeline Conference, 2-4 February 1972. National Research Council of Canada, Ottawa. Technical Memorandum 104. NRCC 12498. v + 331 pp.

MacKay, J. R. 1970. Disturbance to the tundra and forest tundra environment of the Western Arctic. Can. Geotech. J. $7: 420-432$.

Muir, D. 1971. The environmental crisis in the Arctic. Blue Jay 29:172-178. 